ALMANYA'DA

\section{POPÜLİST ALTERNATIF:} DIE LINKE ÖRNEĞİ

\author{
Şenol ARSLANTAŞ \\ Dr.Öğr.Üyesi, İstanbul Üniversitesi \\ Siyasal Bilgiler Fakültesi \\ Siyaset Bilimi ve Uluslararası İlişkiler \\ Bölümü \\ senol.arslantas@istanbul.edu.tr

\section{Düzgün ARSLANTAŞ} \\ Doktora Sonrası Araştırmacı, Köln \\ Üniversitesi \\ Karşılaştırmalı Siyaset Bölümü / Max \\ Planck Enstitüsü Toplum Çalışmaları \\ ad@mpifg.de
}

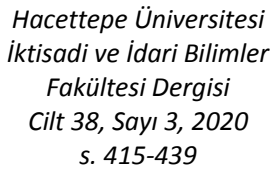

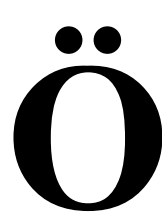

z: $2007-2008$ finansallaşmış kapitalist krizin patlak vermesinin ardindan Avrupa'da ulusal hükümetlerin kemer sıkmaya yönelmesi, ağır sosyal sonuçlara yol açmıştır. $\mathrm{Bu}$ durum, birçok ülkede siyasi memnuniyetsizliği tetikleyerek güçlü radikal partilerin ortaya çıkmasına zemin hazırlamıştır. $\mathrm{Ne}$ var ki kemer sıkma çağında radikal aktörlerin eş zamanlı yükselişine rağmen siyasal partiler çalışmalarında radikal sol partilerin atılımı büyük oranda göz ard1 edilmektedir. $\mathrm{Bu}$ boşluğun doldurulması için makalede, Almanya'da Die Linke örneklemi üzerinden radikal solun evrimi, yapısal politik ekonomik ve politik kurumsal koşullar, toplumsal protesto dinamikleri ve toplumsal hareketlilik açısından analiz edilmektedir. Die Linke'nin yükselişinde ülkede sosyal adalet talebinin temel temsilcisi haline gelerek parti sisteminde SPD'nin geleneksel olarak işgal ettiği yere kaymasının kritik bir rol oynadığ savunulmaktadır. Bununla birlikte 2013 sonrasında radikal sağ AfD'nin kamusal söylemi ve parti rekabetini belirleyen konuları tayin etmesiyle birlikte radikal solun atılım dönemi sona ermiştir.

Anahtar Sözcükler: Die Linke, SPD, radikal sol partiler, sosyal demokrasi, popülizm, radikal să partiler. 

THE POPULIST

\section{ALTERNATIVE IN GERMANY: THE CASE OF THE DIE LINKE}

\author{
Hacettepe University \\ Journal of Economics and \\ Administrative \\ Sciences \\ Vol. 38, Issue 3, 2020 \\ pp. 415-439
}

\author{
Şenol ARSLANTAŞ \\ Assist.Prof.Dr., University of Istanbul \\ Faculty of Political Sciences \\ Department of Political Science and \\ International Relations, \\ senol.arslantas@istanbul.edu.tr.

\section{Düzgün ARSLANTAŞ} \\ Postdoctoral Researcher, University of \\ Cologne \\ Department of Comparative Politics / \\ Max Planck Institute for the Study of \\ Societies \\ ad@mpifg.de
}

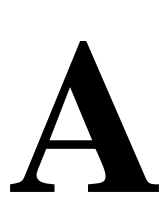

bstract: Following the outbreak of the financialized capitalist crisis of 2007-2008, the adoption of the austerity by national governments in Europe has led to severe social consequences. This has also triggered political dissatisfaction in many countries, paving the way for the emergence of powerful radical actors. However, despite the simultaneous rise of radical actors in the age of austerity, the breakthrough of radical left parties has been largely ignored in political party studies. In order to fill this gap, the evolution of the German radical left through the case of the Die Linke has been analyzed with regard to structural political economic and political institutional conditions, social protest dynamics, and social mobilization. It is argued that the move of the Die Linke to the place that was traditionally occupied by the SPD through emerging as the main representative of the demand for social justice in the party system has played a critical role in the rise of this party. Nonetheless, following 2013, the radical right's successful determination of the public discourse and the issues that determined party competition have ended the breakthrough of the radical left.

Keywords: Die Linke, SPD, radical left parties, social democracy, populism, radical right parties. 


\section{GíRiş}

2007 - 2008 finansallaşmış kapitalist krizin patlak vermesinin ardından Avrupa siyasetinin geleneksel ayarlarında radikal değişimler gözlemlenmiş̧tir. Siyasi değişimin tetikleyici unsuru ise ulusal hükümetlerin kriz yönetim stratejisi olarak daha eşitlikçi, dayanışmacı ve sosyal alternatiflere yönelmek yerine, kemer sıkmayı benimsemesi olmuştur. Özü itibarıyla özel çıkarların zararlarını kamusallaştırarak krizin maliyetini işçi sınıfı ve orta sınıfın alt tabakaları gibi yoksul gruplara yükleyen kemer sıkma, özellikle kırılgan ekonomilere sahip Güney Avrupa ülkelerinde sosyal yeniden üretimi dahi zorlaştırmıştır. Erken dönemlerinde ana akım kriz yönetim stratejisine yönelik tepki, toplumsal hareketliliğin artması ve kitlesel protestolar şeklinde cisimleşirken; devletlerin çeşitli müdahalelerinin ardından eylemliliklerin sona ermesiyle birlikte vatandaşların öfkesi siyasal alana kaymıştır.

Kemer sıkma çağında Avrupa'da yapılan seçimler, parti sistemlerinin geleneksel ayarlarını bozmuştur. Seçimlere katılımın düşmesi ve liberal demokratik kurumlara ve demokrasiye yönelik güvenin erozyona uğraması gibi birtakım ciddi semptomların yanında, söz konusu döneme ana akım aktörlerin düşüşüne paralel olarak kemer sıkma karşıtı (popülist) radikal partilerin başarıları damgasını vurmuştur. Vatandaşların geleneksel partilerden koparak farklı siyasi aktörler etrafında yeniden gruplaşma eğilimi içerisinde olduklarını kanıtlayan bu durum, aynı zamanda parti sistemlerinin yeniden yapılandırıldığı anlamına gelmektedir. Tüm bu hususlar bağlamında Avrupa'da bir siyasi paradigma değişikliğinden söz etmek mümkündür.

Avrupa parti sistemlerinde ana akım aktörlerin hegemonyasını ortadan kaldıran radikal aktörler, sağda ve solda eş zamanlı olarak belirmesine ve istatistiki (seçim sonuçları) açıdan benzer bir değere sahip olmasına rağmen siyasi partiler çalışmalarında radikal sola yönelik ilgi düşük düzeyde kalmıştır. Sola yönelik ilgisizliğin politik / normatif boyutları bulunmakla birlikte yalnızca kemer sıkmanın sosyal tahribatının en açık biçimde deneyimlendiği Yunanistan ve İspanya gibi çevre ülkelerde değil, aynı zamanda gelişmiş kapitalist ekonomilere sahip Almanya ve Fransa gibi ülkelerde de radikal solun atılım dönemine girmiş olması, detaylı biçimde anlamlandırılmayı hak eden bir araştırma sahasına dönüşmüştür.

Dile getirilen hususlar bağlamında bu çalışmada, Avrupa'nın iktisadi, siyasi ve demografik açıdan en güçlü ülkelerinin başında yer alan Almanya'da radikal sol Die Linke'nin parti sistemi üzerindeki değișen rolüne odaklanılmaktadır. Kayda değer biçimde kemer sıkma çağında ülkede Alman Sosyal Demokrat Partisi (SPD) ve Yeşil Parti (Yeşiller), karşılarında yükselişe geçen Die Linke'yi bulurken; Hristiyan Demokrat Partisi (CDU) / Hristiyan Sosyal Birliği (CSU) ile Hür Demokratik Parti (FDP) ise 
radikal sağ (popülist) Almanya için Alternatif Partisi'yle (AfD) baş etmek durumunda kalmıştır.

$\mathrm{Bu}$ arka plan ekseninde, araştırmada, SPD’nin Alman solu üzerindeki hegemonyasını sona erdiren Die Linke'nin evrimi, yapısal politik ekonomik koşullar, politik kurumsal koşullar, toplumsal protesto dinamikleri ve toplumsal hareketlilik açısından ele alınmaktadır. Temel olarak SPD'nin geleneksel programına yabancılaşarak sağa kaymasının ardından parti sisteminde oluşan boşluğun sosyal adalet talebinin temsilciliğine soyunan Die Linke tarafından başarılı biçimde doldurulduğu; ancak popülist milliyetçi sağın yükselişiyle birlikte bu başarının önemli oranda sınırlandırıldığı savunulmaktadır.

Makalenin ilk bölümünde Alman solunun tarihsel evrimi, ikinci bölümünde erken kemer sıkma çağında (2007 - 2013), üçüncü bölümde ise geç kemer sıkma çağında (2014 - 2017) soldaki yeniden gruplaşma eğiliminin temel dinamikleri mercek altın alınmaktadır.

\section{ALMAN SOLUNUN TARIHSEL EVRIMI}

19. yüzyılın ikinci yarısından itibaren Avrupa'da emek örgütlerinin oluşumuna ve işçi sınıfının partileşmesine öncülük eden Almanya'da 1875 yılında Gotha'da kurulan SPD, sendikalarla kurduğu organik ilişkiler sebebiyle seçimlerde işçi sınıfı oylarını domine ederek önemli seçim başarıları elde etmiştir (Çubukçu, 2013). Ne var ki gerek 1. Dünya Savaşı'nda ulusal burjuvazinin militarist eğilimine gerekse de 1917 yılında Rusya'da meydana gelen Bolşevik devrimine karşı alınacak pozisyon konusunda yoğunlaşan parti içi tartışmalar nedeniyle SPD bölünmüş ve Aralık 1918'de Marksizme bağlılığını sürdüren Rosa Luxemburg ve Karl Liebknecht gibi isimlerin öncülüğünde Alman Komünist Partisi (KPD) kurulmuştur. KPD’nin kurulmasıyla Avrupa solunda keskin bir bölünmeye işaret eden sosyal demokrat - komünist parti ikiliği, Almanya'da da somutlaşırken; söz konusu ayrılık nedeniyle 1933 Temmuz'unda ülkede faaliyet gösteren tüm partileri yasaklayan nasyonal sosyalist rejime direnecek bir sol cephe umudu da ortadan kalkmıştır.

Soykırımlara ve milyonlarca masum vatandaşın katledilmesine yol açan Nazi iktidarı, her ne kadar 2. Dünya Savaşı sırasında esasen düşman olan kapitalist ve komünist bloğun ittifakıyla yenilgiye uğratılmış olsa da; savaşın ardından başlayan Soğuk Savaş nedeniyle Almanya ikiye bölünmüştür. Soğuk Savaş’ın siyasi kutuplaşma mantığını özetleyecek biçimde SSCB’nin nüfuzu altındaki ülkenin doğusunda Alman Demokratik Cumhuriyeti (ya da Doğu Almanya); Amerikan, İngiliz ve Fransız devletlerinin nüfuzu altındaki ülkenin batısında ise Almanya Federal Cumhuriyeti (ya da Batı Almanya) kurulmuştur (Eisenberg, 1996). 
İki devletli çözümün kurumsallaşmasını takiben Doğu Almanya'da sosyal demokrat parti, Batı Almanya'da ise komünist parti yasaklanmış ve böylece solun farklı unsurlarının birbirlerine karşı düşmanlaştığ1 bir iklim oluşmuştur (Major, 1997). Ağustos 1961'de yapımına başlanan ve Doğu'dan Batı'ya kaçışların engellenmesi için iki ülke halklarını ayırmak maksadıyla inşa edilen Berlin Duvarı ise aynı dönemde ideolojik kamplaşmasının sembolü olmuştur.

İki ülkenin parti sistemleri birbirlerinden oldukça farklılaşmıştır. Batı Almanya'da çok partili siyasi yaşam; Doğu Almanya'da ise Almanya Sosyalist Birlik Partisi (SED) adı altında tek parti iktidarı kurumsallaşmıştır. Genel hatlarıyla Batı Alman parti sistemi, uzun yıllar boyunca CDU / CSU ve SPD'nin seçimlerde büyük başarılar elde ettiği, ancak koalisyonların daha çok FDP tarafindan belirlendiği bir görünüm arz ederken; 1980'lerin başından itibaren bu partilere çevrecilik ve nükleer karşıtlığ gibi yeni talepleri başarılı biçimde politize eden Yeşiller katılmıştır (Mewes, 1983; Saalfeld, 1990).

Buna karşı1ık Doğu Almanya'da ise radikal biçimde değişen uluslararası konjonktürün etkisiyle 1980 'lerin sonlarında oldukça çalkantılı bir dönem yaşanmıştır. 1989 yılında Berlin Duvarı'nın yıkıldığı ve komünist rejimin sona erdiği ülkede SED, yoluna ancak 4 Şubat 1990 tarihinde Demokratik Sosyalist Parti (PDS) adiyla komünist olmayan bir sol partiye evrilerek devam edebilmiştir (March, Mudde, 2005: 29).

Yapılan görüşmelerin ardından 3 Ekim 1990'da iki ülke Almanya Federal Cumhuriyeti çatısı altında yeniden birleşmiştir. Yeni dönemde PDS, bir yandan sorunlu gördüğü Stalinist geçmişiyle hesaplaşırken, diğer yandan ise SED'den devraldığı çeşitli örgütsel ve finansal kaynaklarla ve Alman birleşmesinin eşitsiz doğasını politize ederek hayatta kalmayı başarmıştır (Oppelland, 2012).

"Doğu Almanya'nın sosyal, iktisadi ve politik geçmişinden tamamen soyutlanarak tek taraflı olarak Batı Almanya'ya eklemlenmesi şeklinde gerçekleşen" yeniden birleşme süreci, ilkinde yüksek işsizlik ve yoksulluk, bilinçli sanayisizleştirme politikaları, cinsiyet eşitsizliklerinin derinleşmesi, yoğun göç ve komünist düzenin aksine zayıf sosyal devlet şeklinde cisimleşmiştir (Hudson, 2000). Böylece Doğu Almanya, Başbakan Helmut Kohl'un (CDU) tüm söylemlerinin aksine, birleşmenin kaybedeni olmuştur (Arzheimer, 2006: 792).

Buna rağmen Batı Alman partileri, bölgede yükselen sorunlara duyarsız kalmış ve bölge halkında federal kurumlara yönelik güveni erozyona uğratmıştır. Bu koşullar altında ve kullanışlı geçmişinden de faydalanmak suretiyle PDS, daha fazla sosyal adalet, eşitlik ve refah devleti talebinde bulunan Doğu halkının siyasi temsilciliğine yönelmiştir (Hough, Kob, 2009). Bununla birlikte seçimlerde Doğu eyaletlerine sıkışan 
parti, Batı eyaletlerinde örgütlü sınıfların desteğini alan SPD’yle baş edemediği için parti sistemine ancak tali yönden eklemlenebilmiştir.

Öte yandan 1990'larda Almanya'da yaşanan iktisadi daralma, düşük ücret artış1, yüksek işsizlik, sermayenin ucuz emeğin yaygın olduğu coğrafyalara yönelmesi ile toplumsal eşitsizliklerin artması gibi gelişmeler nedeniyle seçmenlerin siyaset kurumundan temel talebi, sosyal adaletin sağlanması olmuştur (Storm, Naastepad, 2015: 17). 1998 seçimlerinde Alman solunun zaferi, daha çok sosyal sorunlara sirt çeviren sağın cezalandırılmasıyla mümkün olmuştur. Ne var ki seçimlerin ardından kurulan SPD - Yeşiller hükümeti (1998 - 2005), Oskar Lafontaine gibi geleneğe bağlılığını sürdüren sol sosyal demokratlar dışında, sorunların kaynağını kurutmak için sağ partilerinin dahi siyasi maliyeti nedeniyle çekindikleri neoliberal emek piyasası ve refah devleti düzenlemelerine -bunlardan en ünlüsü 'Hartz IV reformları' olmak üzere- imza atmıştır (Kitschelt, Streeck, 2003).

Bu yaklaşımın teorik arka planında, İngiliz sosyolog Anthony Giddens'in İngiliz İşçi Partisi'ne önerdiği 'Üçüncü Yol' yaklaşımının benzeri olan ve neoliberal küreselleşmeyle uyumlu olacak biçimde geleneksel sosyal demokraside revizyon öngören 'Neue Mitte' (Yeni Merkez) yaklaşımı yer almaktadır. Almanya'nın politik ekonomisinin ve sosyal ayarlarının neoliberal yeniden yapılandırmaya uygun olarak dönüşmesini arzulayan bu yaklaşım, daha az sosyal koruma ve mini-işlerin (mini-jobs) yaygınlaşması gibi sosyal olarak geriletici sonuçlar doğurarak sosyal demokratların siyasi intiharıyla sonuçlanmıştır (Dingelday, 2007: 832).

Sosyal demokratların $\mathrm{u}$ dönüşü, aynı zamanda toplumsal protestoları ve hareketleri canlandırarak partiyi (ve sosyal demokrat sendikaları) içeriden bölmüştür. Yine Hartz reformlarına karşılık sosyal adalet temasını merkezine koyan Emek ve Sosyal Adalet - Seçim Alternatifi (WASG), bu bölünmenin bir sonucudur (Olsen, 2007: 207). İşçi sınıfının terk ettiği SPD’nin alternatif Alman solunu çökertmek için ürettiği stratejiler (seçimleri erkene alma gibi) ise Doğu (PDS) ve Batı (WASG) solunun 2005 seçimlerinde ortak listeyle (Linkspartei.PDS) yarışması sonucunu doğurmuştur (Patton, 2013: 220).

Parti sisteminde SPD’nin geleneksel olarak işgal ettiği yere kaymak için kampanya döneminde sosyal adalet, yoksullukla mücadele, yeniden dağıtım, adil vergilendirme, prekaryalaşmanın sona erdirilmesi ve devlet aktivizmi gibi temalara yoğunlaşan sol ittifak, Eylül 2005 federal seçimlerinde yüzde 8.7 oyla 54 temsilci kazanarak SPD’nin soldaki hegemonyasını sona erdirmiştir. Bu aşamadan sonra Alman solunda yeniden gruplaşma eğilimi, popülist milliyetçi sağın (ya da radikal sağın) yükselişine dek, görece güçlü biçimde hissedilmiştir. Artan siyasi memnuniyetsizlik, 
son tahlilde Alman siyasetinde nadiren rastlanan bir unsur olarak CDU / CSU ve SPD’yi büyük koalisyonda bir araya getirmiştir (Proksch, Slapin, 2006).

\section{RADİKAL SOLUNUN YENIDEN KURUMSALLAŞMASI: DIE LINKE}

\subsection{Solda İttifak Çabalarının Esasları}

Yeniden birleşen Almanya'da ideolojik ve programatik talepleri itibarıyla sosyal demokratların solunda yer alan radikal solun tüm yok olacağı beklentisine rağmen seçim sonuçları açısından atılım dönemine girmesinde en etkili olan husus, CDU / CSU ve SPD gibi ulusal parti sistemini uzun yıllardır domine eden siyasi aktörlerin birleşme sürecinin yol açtığ iktisadi ve sosyal sorunlara yanıt verememesidir. Doğu eyaletlerinde kayda değer düzeyde bir siyasi memnuniyetsizliğin açığa çıkmasına neden olan bu durum, aynı zamanda Almanya'da uzun yıllar sonra ilk kez güçlü bir alternatif sol partinin ortaya çıkmasına zemin teşkil etmiştir.

Spesifik olarak, SPD’nin işçi sınıfı ve orta sınıfın alt tabakaları gibi gerek yeniden birleşmenin gerekse de küreselleşme ve Avrupa entegrasyonu gibi süreçlerin politik ekonomide meydana getirdiği yapısal değişimlerden olumsuz etkilenen grupları siyasi açıdan temsil etme iddiasından vazgeçmesi, Alman parti sisteminde dışlanma, güvencesizleştirme ve prekarya istihdam gibi kayda değer meseleleri politize edecek yeni bir sol partiye ihtiyacı belirgin hale getirmiştir (Nachtwey, Spier, 2007: 124). 2005 seçimlerinde WASG-PDS ortaklığı, ana akım aktörlerin atıllığında bu ihtiyaca yanıt vermeye aday en önemli aktör olarak ön plana çıkmıştır. Radikal solun vatandaşların dile getirdiği taleplerin sözcülüğüne soyunması, ülkede politik söylemi de "asgari ücret, alt sınıflar ve sosyal adalet konularında sola kaydırarak ana akım partileri bir nevi sosyal demokratlaşmaya zorlamıştır" (Solty, 2008: 17-18).

Öte yandan ağırlaşan koşullar altında vatandaşların daha fazla sosyal koruma ve devlet müdahalesi talebinde bulunması, parti rekabetinin temel dinamikleri üzerinde de belirleyici olmuştur. Her şeyden önce ana akım partilere yönelik genel memnuniyetsizlik, SSCB sonrası dönemde gözden düşen radikal sol için bulunmaz bir siyasi firsat penceresi yaratmıştır. Söz konusu süreç, birleşmenin ardından birbirlerinden kopuk bir seyir izleyen Batı ve Doğu Alman solunu birbirlerine yakınlaştırmış ve tüm ideolojik, programatik ve stratejik farklılıklara rağmen solun yeni kurulması planlanan bir sol çatı partisi altında birleşme çabalarını hızlandırmıştır. Gerekli altyapı çalışmalarının ardından Die Linke (Sol Parti), 16 Haziran 2007 tarihinde kurulmuştur (Charalambous, 2011: 306). 


\subsection{Die Linke'nin Temel Politikaları}

Alman solu içerisindeki farklı eğilimleri aynı şemsiye altında bir araya getirmeyi amaçlayan Die Linke'de reformist ve fundamentalist kanatlar arasında çekişmeler yaşanmıştır. $\mathrm{Bu}$ gruplardan ilki, geleneksel sosyal demokrat talepleri, SPD’yle koalisyonlara yeşil 1şık yakılmasını ve Keynezyen korumacılı̆̆ı; ikinci grup ise parlamento dışı bağların kuvvetlendirilmesini, SPD’yle ilişkilere mesafe konulmasını ve daha sol politikalar izlenmesini savunmuştur (Hough, 2010: 146). Parti kongrelerinde ikili arasındaki çekişmeyi reformistler kazanmış ve böylece partinin programatik açıdan geleneksel sosyal demokrat programı hatırlatan bir içerikle seçmenlerin karşısına çıkmasına zemin hazırlamıştır. Öte yandan solun tek çatı altında birleşmesini bariz biçimde kolaylaştıran güçlü parti içi demokrasi vurguları nedeniyle yazılması geciken parti programı, ancak Aralık 2011'de onaylanabilmiştir.

Genel hatlarıyla değerlendirildiğinde, Die Linke'nin parti programı, demokratik sosyalist / demokratik sol değerlere vurgu yapmaktadır. PDS'yi hatırlatacak biçimde Stalinizm karşıtı bir siyasal pozisyona sahip olan ve Marksizme ve Leninizme referans vermekten kaçınan Die Linke, liberal parlamenter sistemi benimsemektedir (Taylor, 2009). Bu minvalde solun teleolojisinde yer alan sosyal devrim düşüncesini ve onun siyasi kurumsallaşmasını (tek parti iktidarı gibi) reddeden partinin kapitalizme karşı pozisyonu ise belirsizdir.

$\mathrm{Bu}$ belirsizliğin nedenlerinden biri, yeni partinin Alman solunu bir araya getirmeyi amaçlayan bir şemsiye örgüt gibi hareket etme isteğinden kaynaklanmaktadır. Dolayısıyla kapitalizm eleştirisi açısından partide farklı görüşler mevcuttur. Örneğin sol aktivistler, "kapitalizm karşıtı yeni bir sosyal ve iktisadi düzene geçilmesini" savunurken; daha 1lımlı bir rota izleyenler ise "sistem içerisinde çözümün mümkün olduğunu” iddia etmektedir (Hildebrandt, 2011: 107-108). Kararları etkileme kapasitesi açısından ise ikinci görüşü destekleyenler, kısa süre sonra parti yönetimine hâkim olarak radikal ajandanın terk edilmesi sonucunu doğurmuştur.

Anti-kapitalist bir parti olmamakla birlikte Die Linke, anti-neoliberal karakteristiklere sahiptir. Devletin iktisadi faaliyetlerini bir bakıma askıya alarak serbest piyasa mekanizmasının doğal sonuçlarına kutsallık atfeden neoliberalizme karşılık parti, üretim ve dağıtım ilişkileri açısından piyasa düzenlemelerinin demokratik, sosyal ve ekolojik çerçeveye ve kontrole tabi tutulmasını amaçlamaktadır. Parti programında 'demokratik ekonomik düzen' olarak tarif edilen kapitalizme yeni ilişkilenme biçiminin asli unsurunu ise sosyal çıkarı gözeten ve demokratik kontrole tabi bir mülkiyet anlayışı oluşturmaktadir.

Kapitalist aşırılıkları törpülemeye odaklanan parti, sosyo-ekonomik meselelerin yanında, 'yeni politika' alanlarına açılmayı da ihmal etmemiştir. Böylece kapitalizmin 
doğayla kurduğu yıkıcı ilişkiye karşı çıkan ekolojistler başta olmak üzere postmateryalist değerlere sahip vatandaşlar da potansiyel seçmen kitlesine dahil edilmiştir (Parti Program1, 2011). Ne var ki parti sisteminde Yeşiller gibi temel olarak beyaz yakalı seçmenlerin taleplerini politize eden bir aktörün varlığı, radikal solu zorlaşmıştır.

Die Linke'nin temel hedefi, 1980'lerin başından itibaren sosyal demokratların sirt çevirdiği 'sosyal sorunu' yeniden gündeme taşımak olmuştur. Doğu eyaletlerinde daha keskin biçimde hissedilmekle birlikte acil biçimde çözüm bekleyen sosyal sorunun çözümü noktasında parti, güçlü refah devletinin kurumsallaşması, adil vergilendirme yoluyla yeniden dağıtımın zenginden yoksula olacak şekilde yeniden belirlenmesi, ücret eşitsizliklerinin giderilmesi, cinsiyet eşitsizliklerini derinleştiren uygulamalara son verilmesi, ücretsiz eğitim hakkı sağlanması, emek piyasasında prekaryalaşmaya neden olan düzenlemelerin iptal edilmesi, sendikal örgütlenmelerin desteklenmesi ve ekonomik kararlarda işverenlerin yanında işçilerin ve sendikaların da söz sahibi olması gibi politikalar önermiştir (Parti Programı, 2011).

Sosyal adalet talebini merkeze alan bir yaklaşımla daha insancıl bir kapitalizmin inşa edilmesine yönelen Die Linke, özellikle işçi sınıfı ve orta sınıfın alt tabakalarında etkili olmaya başlamıştır. Ayrıca partinin sosyal programı, popülist söylemin toplumu mobilize edici nitelikleriyle güçlendirilmiştir (Hough, Kob, 2009). Geleneksel sol siyasete hâkim olan sınıf dilinin aksine kendisini masum halkın savunusu fikrine dayandıran popülist söylem, (Batılı) seçkinlerin topluma ihanet ettiği iddiası ile büyük ve kötü işverenlere karşı mücadele edileceği gibi vaatlerle güç kazanmıştır. Bu itibarla Die Linke'nin soldaki boşluğu doldurmasında yalnızca diğer partilerin başarısız politikalarının değil, aynı zamanda "güçlü parti söylemi" de etkili olmuştur (Kü̧̈ükali, 2014).

Kapitalizmin sosyal eleştirisinin yanında, liberal siyasi kurumların eksiklikleri de masaya yatırılmıştır. Bu bağlamda ön plana çıkan hususların başında, siyasi karar alma süreçlerinin demokrasi açığıyla malul olduğu düşüncesi yer almaktadır. Temsil düşüncesine gereğinden fazla vurgu yaparak doğrudan demokrasiden uzaklaşan mevcut siyasi-kurumsal sistemin yeniden ayağa kalkması için referandum kartının kullanılması gerektiği düşünülmektedir.

Masum halk - yozlaşmış yönetici sınıf ikiliği üzerinden tartışıldığı durumlarda zamanın ruhuna uygun bir popülist sol vaat olarak da düşünülebilecek olan referandumlar yoluyla vatandaşların yaşamlarını ilgilendiren meselelerin çözümünde doğrudan inisiyatif alarak halkın kararlara katılımının özendirilmesi amaçlanmaktadır. Aynı zamanda iktisadi, sosyal ve cinsiyet ilişkileri gibi insan yaşamının farklı alanlarının aynı anda demokratikleştirileceği ifade edilerek mevcut pratiklerin ötesinde 
bir demokrasi anlayışının inşa edilmesi arzusu gündeme taşınmıştır (Parti Programı, 2011).

\section{ERKEN KEMER SIKMA ÇAĞINDA ALMAN SIYASETİ (2007 - 2013): SOLDA YENIDEN GRUPLAŞMA EĞİLIMININ IZLERİ}

\subsection{Ekonomik Krizin Etkileri ve Kriz Politikaları}

Kapitalizmin yol açtığ sosyal sorunlara ve liberalizmin temsil krizine aynı anda yanıt vermeyi amaçlayan Die Linke'nin kuruluşu, 2007 - 2008 finansallaşmış kapitalist krizin etkilerinin Avrupa'da hissedildiği bir döneme rastlamaktadır. Bu nedenle söz konusu dönemin en önemli gündem başlığı, ekonomik krizle mücadele meselesi olmuştur. Esas itibarıyla parasal birliğe üyeliğin (1999) politik ekonomide meydana getirdiği değişikliklerin $\mathrm{AB}$ içerisinde merkez üyelere sağladığı çeşitli ayrıcalıklardan yararlanan Almanya, ihracat güdümlü sanayi ekonomisiyle pazar çeşitliliğini artırarak ve ileri teknolojilere yönelerek büyük ticaret fazlaları vermiş ve tüm bu nitelikleri itibarıyla AB'nin ağırlık merkezini oluşturmuştur (Dyson, 2008). Yine AMB'nin Frankfurt'ta bulunması, Almanya'nın $\mathrm{AB}$ içerisindeki içerisindeki hâkim rolünün dişavurumudur. Öte yandan ulusal ekonominin özellikle rekor düzeydeki ticaret fazlalarıyla somutlaşan başarılı performansı, Portekiz, Yunanistan ve İspanya gibi çevre ülkelere yapısal açık şeklinde yansıyarak periferide kırılganlığı artırmıştır (McGiffen, 2011: 30-31).

Her ne kadar düşük faiz ve likidite bolluğu ortamında iktisadi açıdan eşitsiz ve dengesiz gelişme dinamiği gizlenmiş olsa da, krizin sarsıcı dalgalarının Avrupa kıyılarına ulaşmasıyla $\mathrm{AB}$ içerisindeki işbölümü belirgin hale gelmiştir. Birlik içerisindeki yapısal sorunları açığa çıkaran bu durum, aşamalar halinde gerçekleşmiştir. İlk etapta kriz, ABD’yle kurulan yakın iktisadi ve finansal ilişkiler nedeniyle Almanya gibi merkez ülkelerin ekonomilerinde ciddi bir durgunluğa yol açmıştır (Bieling, 2012: 259). Özellikle Almanya'nın ihracat güdümlü ekonomisi, iktisadi faaliyetlerin yavaşlaması, yatırımların düşmesi ve tüketimin azalması gibi nedenler sonucunda bocalama dönemine girmiştir. Ardından ulusal ekonomide kısa süreliğine de olsa bir daralma süreci yaşanmış; ancak birkaç çeyreklik küçülmeyi takip eden y1llarda söz konusu manzara kayda değer biçimde değişmiştir.

Erken iyileşmenin çeşitli nedenleri bulunmaktadır. Her şeyden önce Almanya, 1980'lerden itibaren Avrupa'nın kapitalist ekonomilerinin temel gelişme dinamikleri içerisinde yer alan finansallaşma olgusundan diğer ülkelere kıyasla daha az etkilenmiştir. Güçlü sanayi ekonomisini koruyan ülkede finansallaşma düzeyinin düşük düzeyde kalması, bir avantaj olarak belirmiş ve krizin etkilerinin daha kolay biçimde çevrelenmesi sonucunu doğurmuştur (Bieling, 2014). Benzer biçimde Almanya, diğer pek çok ülkenin aksine emek gücünü uzun yıllar önce disipline ederek krizin maliyetini 
azaltmıştır. Üretkenlik artışının altında kalan ücretlerin sendikalara kabul ettirilerek emek maliyetlerinin bilinçli biçimde düşürülmesi ve iç talebin baskılanması yoluyla ihracat odaklı ekonomik gelişme modelinin sürekliliğinin sağlanması gibi stratejiler, kriz ortamında devasa cari işlem fazlalıklarının korunması açısından da hayati rol oynamıştır.

Bununla birlikte hükümet, bir dizi tedbiri hayata geçirmek zorunda kalmıştır. Ekonomik canlandırma paketlerinin ilan edilmesi, şirketlerin üzerindeki yükü azaltmak maksadıyla çalışanların iş sürelerinin kısaltılması, borçlanma maliyetlerinin düşürülmesi, krizden etkilenen şirketlere çeşitli destekler sağlanması ve Batı ekonomilerinde meydana gelen daralmaya karşılık Alman sermayesinin başka pazarlara açılmasının desteklenmesi gibi girişimler, bu yönde atılan adımlar arasında yer almaktadır (Wolf, 2015: 88-89; Akçay, Güngen, 2016: 156).

\subsection{Radikal Solun Atılımı: 2009 Seçimleri}

Her ne kadar söz konusu tedbirler, kısa sürede meyvelerini vermiş ve Almanya, AB'nin dinamosu olmayı sürdürmüşse de, yaklaşan 2009 Avrupa Parlamentosu ve federal seçimleri öncesinde yaşanan belirsizliklerin sürmesi ile daha dayanışmacı, eşitlikçi ve sosyal alternatif kriz stratejilerinin hükümet tarafından dışlanması nedeniyle kaygılar artmıştır.

CDU / CSU ve SPD tarafindan izlenen kriz yönetim stratejisi, Die Linke tarafindan ağır biçimde eleştirilmiş̧ir. Radikal sol, hükümetin yürütmekte olduğu politikalarla krizin faturasını sosyal açıdan dezavantajlılara (iş̧̧i sınıfı ve orta sınıfin alt tabakaları gibi) yüklediğini belirterek kriz politikalarına karşı çıkmıştır. Buna karşılık savaş sonrası dönemde Avrupa'nın politik ekonomisinde yükselişe geçen 'sosyal demokrat uzlaşı'yı hatırlatacak biçimde Die Linke, bankaların millileştirilmesi, Keynezyen politikaların devreye sokulması yoluyla tam istihdamın sağlanması, kamu hizmetlerinin ve refah yardımlarının güçlendirilmesi yoluyla kapitalizmin sosyal krizinin sonlandırılması, asgari ücretin artırılarak vatandaşların yaşam standartlarının yükseltilmesi, finansal risklerin azaltılması için hedge fonlarının yasaklanması ve finansal piyasaların daha sıkı denetlenmesi gibi talepleri dile getirmiştir (Bowyer, Vail, 2011: 684; Bailey, 2016: 58).

Aynı zamanda parti, Alman hükümetinin izlediği politikaların AB içerisinde de büyük bir yıkıma yol açtı̆̆ını iddia etmiştir. Bu itibarla Avrupa ekonomilerini sarsan kriz olgusunu ülkenin iç dinamikleriyle birlikte okuyan Die Linke, özellikle SPD Yeşiller hükümetinin emek piyasasında ve refah devletinde neoliberal revizyon öngören 'Ajanda 2010' programını devreye sokarak diğer ülkeleri bütçe açığı vermeye zorladığını belirtmiştir. Yine Başbakan Angela Merkel'in (CDU) ülke içerisinde kemer 
sıkmaya izin vermemesine karşılık, AB'nin kırılgan ekonomilerine kemer sıkmayı dayatması, ikircikli bir tavır olarak değerlendirilmiştir.

$\mathrm{Bu}$ itibarla Merkel'in Avrupa'da krizin en ağır biçimde vurduğu ülkelere mali destek sağlanması için Avrupa Merkez Bankası (AMB), Avrupa Komisyonu ve Uluslararası Para Fonu'ndan (IMF) müteşekkil Troyka'nin uygulanmasını dikte ettiği politikaları destekleyerek çevre ekonomilerde ağır bir sosyal yıkıma yol açtığı iddia edilmiştir. Radikal sol, krizden etkilenen ülkelerin sistemin mağduru olduğunu savunarak, bazı borçların silinmesi, yatırım programlarıyla borçlu ülkelere yardım edilmesi, parlamentoların işverenler ve sanayi lobilerine karşı korunması ve finansal sektörlerin gücünün azaltılması gibi önerileri gündeme taşımıştır (Bouma, 2016: 139). Her ne kadar enternasyonalist ve dayanışmacı izler taşıyan bu öneriler kararlara yansımasa da, Die Linke, sosyal adalet temelinde bir siyasi alternatifi yaratmayı başararak diğer partilerden farklılaşmıştır.

Bu arka plan ekseninde, 2009 Avrupa Parlamentosu (AP) ve federal seçimleri, radikal solun gerek parti rekabetini belirleyen konular gerekse de kamusal söylem üzerindeki artan etkisini kanıtlamaktadır. Bu minvalde 7 Haziran 2009 tarihinde yapılan AP seçimlerinde CDU yüzde 30.7 oyla 34 , SPD yüzde 20.8 oyla 23 , Yeşiller yüzde 12.1 oyla 14, FDP yüzde 11 oyla 12, Die Linke yüzde 7.5 ve CSU yüzde 7.2 oyla 8 sandalye kazanmıştır.

Önceki seçimlerle mukayese edildiğinde, AP seçimlerinin en çarpıcı sonucu, merkez aktörlerin oylarındaki ciddi düşüştür. Buna karşılık Die Linke ise derinleşen eşitsizliklere ve yoksulluğa, sıradan vatandaşın siyasi kararların dışında tutulması girişimine ve Doğu'daki kronik sorunlara karşı mücadele ederek parti sisteminde uzun yıllardır SPD'nin geleneksel olarak işgal ettiği yere kaymıştır. Bir başka deyişle SPD'nin sosyo-ekonomik meselelere bakışında gözlemlenen u dönüşü, yani Keynezyen gelir ve refah adaletsizliklerini önleyen tedbirlerden neoliberal eşitsizliklerin meşrulaşıırmasına yapılan patinaj, solda dengeleri değiştirmiştir.

AP seçimlerinin ardından ülkede 27 Eylül 2009 tarihinde federal seçimler yapılmıştır. CDU, yüzde 27.3 oyla 194 sandalye kazanarak seçimleri ilk sırada tamamlarken, SPD yüzde 23 oyla 146 vekil çıkarmıştır. Seçimlerde FDP yüzde 14.6 oyla 93, Die Linke yüzde 11.9 oyla 76, Yeşiller yüzde 10.7 oyla 68 ve CSU yüzde 6.5 oyla 45 vekil elde etmiş̧tir. Görüldüğü üzere, krizin patlak vermesinin ardından yapılan ilk seçimlerin, sosyal demokratlar olmuştur. Seçimlerde milyonlarca seçmenini diğer partilere kaptıran SPD, yine çok sayıda seçmenini oy vermeye ikna edemeyerek siyasetten soğutmuştur. Vatandaşların alternatif kriz ajandası oluşturamamakla eleştirdiği SPD, özellikle uzun yıllardır kendisine oy veren sadık işçi sınıfı seçmenlerini kaybederek savaş sonrası dönemdeki en kötü seçim performansına imza atmıştır. 
Sosyal demokratlardan kopan vatandaşların soldaki adresi ise Die Linke olmuştur. Batı eyaletlerinde ortalama yüzde 8 , Doğu eyaletlerinde ise yüzde 26 oy alan parti, parlamentoya 76 vekil göndermeye hak kazanarak büyük bir çıkış yakalamıştır. Partinin elde ettiği başarıda özel çıkarı sosyal çıkara önceleyen ana akım kriz politikaları, SPD'nin alternatif bir program yaratmaya yönelik isteksizliği ile izlenen politikalarda vatandaşların taleplerinin ve katılımının dikkate alınmaması gibi nedenler belirleyici olmuştur. Krize yönelik toplumsal tepkinin erken siyasi dişavurumu olan radika sol, bu sonuçla "merkez kapitalist ülkelerde neoliberalizmin çelişkilerinin ilk sol siyasal ifadesi olmuş" ve bir süreliğine de olsa, Almanya'nın "Fransa, Danimarka, Hollanda, Norveç ve İsviçre'nin ardından iş̧̧i sınıfını modern sağ popülizme ya da sağ aşırıcılığa kaptırmasını engellemiştir" (Solty, 2008: 2).

\subsection{Radikal Solun Düşüșü ve 2013 Seçimleri}

Seçimlerin ardından CDU / CSU - FDP hükümetinin kurulduğu ülkede iktidar pratiklerine yönelik toplumsal tepki, kendisini yalnızca 2009 federal seçim sonuçlarıyla cisimleştirmemiştir. Aynı zamanda seçimlerinin ardından ülkede toplumsal hareketlilik de yükselişe geçmiştir. Die Linke, bu süreçte protestocuların siyasi temsilciliğine soyunmak için önemli adımlar atmıştır. Bir yandan Euro Bölgesi'nde uygulanan kemer sıkma politikalarına karşı gerçekleştirilen gösterilere ve özellikle 'Blockupy' protestolarına destek veren parti (Neumayer $v d ., 2016$ ), diğer yandan ise sendikalar ve demokratik kitle örgütleriyle yakın ilişkiler kurarak çevresel bağlantılarını güçlendirmeye yönelmiştir. Bu sayede siyasi seçkinlere yönelik toplumsal tepkileri oya çevirmeyi amaçlayan parti, Alman sağında henüz güçlü bir popülist milliyetçi partinin bulunmaması gibi parti rekabetini ilgilendiren nedenlerin de etkisiyle siyasi tartışmalarda etkili bir taraf olarak ön plana çıkmıştır.

Ne var ki 2009 seçimlerinin ardından ortaya çıkan uygun siyasi iklime rağmen birtakım olumsuz gelişmeler de aynı dönemde baş göstermiş̧ir. Bunların başında, radikal solun federal yönetimlerde yer aldığı Doğu Alman eyaletlerinde yaşadığı bir dizi sorun gelmektedir. Özellikle krizi bahane eden federal hükümetin eyaletlere ayırdığı bütçede kesintiye gitmesi ile emek piyasası ve sosyal devleti ilgilendiren konularda çeşitli reformlar yapması, Die Linke'nin içerisinde yer aldığı eyalet hükümetleri açısından da bağlayıcı sonuçlar doğurarak değişim umudu taşıyan kitleleri hayal kırıklığına uğratmıştır (Hough, 2010: 149).

Partinin sosyal adaletin temsilcisi olma iddiasına ağır darbe vuran bu gelişmelerin ardından radikal solun farklı bir düzen yaratma girişimi sekteye uğramıştır. Ardından radikal solun seçim atılımları sona ermiş ve eyalet seçimlerinden başlamak üzere seçimlerde gerileme dönemi başlamıştır. 18 Eylül 2011'de partinin Berlin seçimlerinde yaşadığı hezimeti, diğer Doğu eyaletlerinde alınan yenilgiler izlemiş ve alternatif sol gözden düşmüştür (Mckay, 2012: 234). 
Alman radikal solunun gerilemesi, Yunanistan'da kemer sıkma destekçisi Panhelenik Sosyalist Hareket'in (PASOK) 2012 parlamento seçimlerinden itibaren seçmenler tarafından ağır biçimde cezalandırılmasına paralel olarak yükselişe geçen ve Ocak 2015 seçimlerini kazanan popülist sol Syriza'nın kemer sıkmaya alternatif bir sosyal ve ekonomik düzen inşa edememesi sonrasında gözden düşmesiyle paralellik içermektedir. Tıpkı Syriza'nın alternatifi inşa edememesinin ardından yaşadığı gibi, Die Linke de Doğu eyaletlerinde ortaya çıkan sosyal sorunlara yanıt verememesinin ardından ivme kaybetmiştir. Dolayısıyla Avrupa'da kemer sıkma çağında ortaya çıkan uygun koşulların varlığına rağmen radikal sol, kemer sıkmanın yapısal sınırlıklarını aşacak alternatif bir iktisadi ve sosyal düzen yaratamamasının bedelini ağır biçimde ödemiştir.

Diğer yandan Alman hükümetinin kriz yönetim stratejisinin kısa sürede başarılı sonuçlar ortaya çıkarması da, radikal solun Yunanistan (Syriza'yla) ve İspanya'da (Podemos'la) gerçekleştirdiği büyük seçim atılımlarını engellemiştir. Açık biçimde 2009 seçimlerinin ardından kurulan Hristiyan demokrat - liberal hükümet, krizin etkilerini kısa süre içerisinde kontrol altına almayı başarmış ve böylece kriz olgusunu dışsallaştırarak Avrupa'da istisnai bir örnek teşkil etmiştir. Bu şaşırtıcı başarı, Alman tahvillerinin Avrupa'nın en güvenilir tahvilleri olmasıyla taçlandırılmıştır. Benzer biçimde, yalnızca kırılgan Güney Avrupa ülkelerinde değil, aynı zamanda Fransa gibi merkez ekonomilerinde de gözlemlenen yüksek işsizlik, Almanya'da gerçekleşmemiştir (Cahuc vd., 2013). Diğer Avrupa ülkelerine benzemeyecek biçimde ülkenin istihdam rakamları kriz döneminde iyileşmiş ve işsizlik $\mathrm{AB}$ ortalamasının yarısına, yani yüzde 5'ler seviyesine gerilemiştir.

Aynı zamanda krizi ekonominin yapısal sorunlarını aşmasına yardımcı olan bir firsata çeviren hükümet, -örneğin krizin vurduğu Polonya, Yunanistan, İtalya ve İspanya'dan gelen göçmenler sayesinde emek gücünü yenileyerek- radikal solun Güney Avrupa'da elde ettiği başarıya benzer bir sonuç elde etmesini engellemiştir. Yine CDU / CSU - FDP ortaklığı, emek piyasasına yönelik herhangi bir radikal reform programına izin vermeyerek kitlesel protestoların önünü almıştır (Akçay, Güngen, 2016: 156). 2011-2013 yılları arasında Avrupa geneline yayılan ve İspanya ve Yunanistan'da büyük siyasi etkileri olan hareketlerin doğmasına neden olan büyük toplumsal hareketlilik, bu nedenle Almanya'da gerçekleşmemiştir.

Kemer sıkmanın acı sosyal reçetesinin ülke içerisinde uygulanmasına izin vermeyen Alman hükümeti, diğer ülkelere ise kemer sıkmayı dayatarak ikircikli bir tavır geliştirmiştir. Genel hatlarıyla değerlendirildiğinde, gerek borç çevrimi sorunuyla karşılaşan ülkelere sağlanan yüz milyarlarca dolarlık banka kredileri gerekse de merkezi Frankfurt'ta bulunan AMB üzerindeki ezici otoritesi nedeniyle AB'de kriz yönetim stratejisini belirleyen temel aktör Almanya olmuştur. İhracat güdümlü ekonomik 
gelişme modelinin sürdürülmesindeki eşsiz katkısı nedeniyle ülkenin kriz yönetim stratejisi açısından temel önceliği, Euro'nun ortak para birimi olarak sürdürülmesi olmuştur (Dyson, 2008: 132). Benzer şekilde, Yunanistan ve İtalya gibi çevre ülkelerin Euro'dan çıkış tartışmalarına en sert tepkiyi veren de, bunları sonlandıran da Berlin yönetimi olmuştur.

Parasal birliğe yönelik tartışmaların sonlandırılmasının ardından Alman ve Fransız siyasi karar alıcıları, kemer sıkma mantığına uygun biçimde neoliberal yeniden yapılandırma öngören uygulamalarla çevre ülkelere mali disipline geçilmesi, emek maliyetlerinin azaltılması ve emek piyasasında deregülasyona gidilmesi gibi konularda baskı yapmış ve Güney Avrupa ekonomilerini yapısal olarak dönüştürmüştür (Akçay, Güngen, 2016: 155; Storm, Naastepad, 2015: 12). Böylece daha homojen bir Avrupa ekonomisi inşa etmeye yönelen merkez ülkeler, AB'nin işbölümünün yol açtığı eşitsizlikleri yeniden üretmiştir.

Ana akım aktörlerin sosyal alternatifleri dışladığı, radikal solun ise yapısal sinırlılıklar nedeniyle farklı düzen taahhüdünün başarısızlığa uğradığı bir konjonktürde ülkede federal seçimlere gidilmiştir. Kampanya döneminde Die Linke, kendisini yine sosyal adaletin temsilcisi olarak tanımlayarak, 10 Euro'luk saatlik asgari ücret uygulamasına geçilmesi, neoliberal emek piyasası düzenleme aracı Hartz IV yasalarının ortadan kaldırılması, sosyal güvenlik ödemelerinde 500 Euro'luk artış sağlanması, emeklilik yaşının indirilmesi, geçici çalıştırmayla mücadele edilmesi ve kamu kurumlarının özelleştirilmesinin durdurulması gibi talepleri gündeme taşımıştır (Hildebrandt, 2013: 153-154). Ne var ki krizin etkilerinin kontrol altına alınması, söz konusu taleplere yönelik ilgiyi azaltmıştır.

Kamusal söylemi tayin etme noktasında vasat bir profil çizen radikal sola karşllık ve Alman parti sisteminin evrimi üzerinde doğrudan etkili olacak biçimde seçimler öncesinde yaşanan en kritik gelişme ise Nisan 2013'te 'Almanya için Alternatif Partisi’nin (AfD) kurulması olmuştur. Özü itibarıyla değerlendirildiğinde, uzun yıllardır Batı Avrupa'daki diğer ülkelerin aksine güçlü bir popülist milliyetçi sağ partinin ortaya çıkmadığı Almanya, atipik bir örnek teşkil etmiştir (Arzheimer, 2015). Bununla birlikte söz konusu aktörlerin politize edebileceği uygun koşullar özellikle son y1llarda olgunlaşmıştır.

Bir yandan ana akım aktörlere yönelik genel memnuniyetsizliğe rağmen CDU / CSU ve SPD arasındaki ideolojik ve programatik farklılıkların yok düzeyine inmesi ve böylece Hristiyan demokratlardan ve sosyal demokratlardan farklılaşan yeni bir partiye ihtiyaç duyulması (Solty, 2008), diğer yandan ise çoğu kez Alman benmerkezciliğinin etkisi altında üretilen ve rrkçı izler de taşıyacak nitelikteki iddialarla birlikte hükümetin krizi dışsallaştırma yöntemi -örneğin çalışkan Alman halkından toplanan vergilerin 
Güney Avrupa'nın tembel halklarının ve beceriksiz yönetimlerinin yol açtığı krizin sonlandırılması için sefer edildiğinin iddia edilmesi gibi- ile göçmen sayısındaki dramatik artış gibi unsurlar, Almanya'da politik rekabetin temel dinamiklerini popülist sağa yarayacak biçimde değiştirmiştir. Erken dönemlerinde daha çok AB ve Euro'ya yönelik eleştirilere ağırlık veren AfD'nin süreç içerisinde göçmen ve İslam karşıtlığı üzerinden yoksulluk ve işsizlik gibi sorunlardan doğrudan olumsuz biçimde etkilenen alt sınıfların kaygılarını politize etmeye yönelmesi (Berbuir vd., 2015: 158), Alman parti sistemi üzerindeki popülist tazyiki somutlaştırmaktadır.

$\mathrm{Bu}$ arka plan ekseninde 22 Eylül 2013 tarihinde gerçekleştirilen federal seçimlerde CDU, yüzde 34.1 oyla 255 vekil elde ederek yarışı ilk sırada tamamlamıştır. Bu partiyi yüzde 25.7 oyla ve 193 vekille SPD, yüzde 8.6 oyla ve 64 vekille Die Linke, yüzde 8.4 oyla ve 63 vekille Yeşiller ve yüzde 7.4 oy ve 56 vekille CSU izlemiştir.

Seçimlerin kaybedeni, 1.4 milyon seçmenini başka partilere kaptıran radikal sol olmuştur. $\mathrm{Bu}$ sonucun çeşitli nedenleri bulunmaktadır. Her şeyden önce partinin toplumsal tabanını genişletmek için Batı eyaletlerine açılma ve sosyal demokratların çöküşünü hızlandırma stratejilerinin iflas etmesi, düşüşü hızlandırmıştır. İkinci olarak, AfD’nin Doğu eyaletlerinde elde ettiği başarılı sonuçlar, solun bölgedeki hâkim pozisyonunu sarsmıştır (Olsen, 2018). Böylece radikal sol açısından krizin yarattığı firsat penceresi, kısa sürede kapanmıştır.

Seçim sonuçları açısından Alman solunu ilgilendiren diğer bir kritik gelişme ise SPD’nin savaş sonrası dönemin en kötü ikinci sonucuna imza atmasına rağmen bir önceki seçimle mukayese edildiğinde oylarını kısmen artırmasıdır. Bu nedenle Alman solunda yeniden gruplaşma eğilimi, kemer sıkma çağında, örneğin Yunan, İspanyol, Fransız ve Portekiz sosyalistlerinin karşılaştıkları hezimetler akılda tutulduğunda, zayıf düzeyde kalmıştır. Belirtilen hususlara ek olarak, sosyo-ekonomik önceliklerin oy verme davranışını yeniden etkilemeye başlamasıyla Yeşiller'in oylarında gerileme yaşanmıştır.

Diğer yandan seçimler, Alman sağı açısından önemli sonuçlar doğurmuştur. $\mathrm{Bu}$ bağlamda FDP, savaş sonrası dönemde ilk kez federal seçim barajının altında kalarak liberalizmi Bundestag'da temsilcisiz bırakmıştır (Zur, 2017). Buna karşılık, AfD’nin özellikle Doğu eyaletlerinde ortaya çıkan sorunlara yönelik geliştirdiği yabanc1 düşmanı, 1rkçı ve refah şövanisti politikalar, bölgede destek bulmaya başlamış ve dolayısıyla Alman sağı üzerindeki Hristiyan demokrat hegemonya sarsılmıştır. Siyasi rekabetin keskinleștiği ülkede CDU/CSU ve SPD, parlamentoya her zamankinden daha fazla aktörün girmesiyle bozulduğunu iddia ettikleri siyasi istikrar ortamını yeniden tesis edebilmek için güçlerini birleştirmeye karar vermiştir. Rakip partilere yönetim 
şansı tanımak istemeyen ve sol koalisyona yeşil ışı yakmayan SPD yönetimi, Hristiyan demokratlarla yeniden büyük koalisyonda bir araya gelmiştir (Faas, 2015: 245).

\section{GEÇ KEMER SIKMA ÇAĞINDA ALMAN SIYYASETİ (2014 - 2017): YENI MEYDAN OKUMALARIN YÜKSELIŞi}

\subsection{Krizin Dışsallaştırılması ve Göç: Popülist Sol Popülist Sağa Karşı}

Tarihsel açıdan değerlendirildiğinde, büyük krizlerin, savaşların ve sosyal çalkantıların ardından gündeme gelen büyük koalisyon olgusu, örneğin Yunanistan'da da aynı dönemde gözlemlendiği üzere, eskisi gibi yönetmenin zorlaştı̆̆ durumlarda ortaya çıkmaktadır. Solda Die Linke, sağda ise AfD'nin güç kazanmasıyla Alman parti sisteminin 2 kutuplu doğası, yani SPD ve Yeşiller'e karşıllk CDU/CSU ve FDP ikilisinin oluşturduğu yapı, açık biçimde ortadan kalkmıştır. Artan siyasi rekabet, AP seçimlerinin sonuçlarına da yansımıştır.

Her şeyden önce ana akım partilerin söylemlerinin birbirlerine yakınlaşması, sandığa yönelik ilgiyi azaltııştır. Bunun yanında, kurumsal açıdan önemli bir gelişme olarak, seçimler öncesinde Anayasa Mahkemesi'nin AP seçimlerinde uygulanan yüzde 3'lük barajı anayasaya aykırı bularak kaldırması, vatandaşların parti sistemine tali yönden eklemlenen küçük partilere daha fazla yönelmesini teşvik etmiştir. Bu koşullar altında 25 Mayıs 2014 tarihinde yapılan AP seçimlerinde CDU yüzde 30 oyla 29, SPD yüzde 27.3 oyla 27, Yeşiller yüzde 10.7 oyla 11, Die Linke yüzde 7.4 ve AfD yüzde 7.1 oyla 7, CSU yüzde 5.3 oyla 5 ve FDP yüzde 3.4 oyla 3 vekil kazanmıştır.

Seçimlerin en çarpıcı sonucu, FDP'deki kan kaybının sürmesi ile özellikle Doğu eyaletlerinde yaşayan seçmenler üzerindeki etkisi her geçen artan AfD'nin güçlü meydan okuması karşısında radikal solun oylarında yaşanan düşüştür. Bu süreçte radikal aktörlerin daha çok birbirleriyle rekabete yönelmesi, ana akım aktörlerin bir süreliğine de olsa rahat nefes almasını sağlamıştır.

2014 AP seçimlerin ardından Alman siyasetinin temel gündem maddesini radikal sağın da yadsınamaz katkısıyla- göçmen meselesi oluşturmuş̧tur. Özellikle 2015 yazından itibaren ülkeye göç eden yabancıların sayısındaki ciddi orandaki artış, ülkede yeni tartışmalara yol açmıştır (Jackle, König, 2017). Bu durumun temel nedeni, iktidar partilerinin göçmenlerin güçlü Alman sanayisinin sürdürülmesindeki ve kozmopolit yapının korunmasındaki önemini vurgulamak yerine, herhangi bir siyasi maliyetle karşılaşmamak için göçmenlere yönelik alternatif bir söylem oluşturmamalarıdır.

Ana akım aktörlerin atıllığında AfD ise artan göçmen sayısını, yeniden birleşmenin ardından beliren sorunlarla ilişkilendirerek toplumsal öfkenin kendilerinden olmayana, yani 'diğerlerine' yönelmesine sebebiyet vermiştir. Bu itibarla kısa süre 
içerisinde yabancı karşıtı ve dışlayıcı söylem, özellikle alt sınıflar için cazip hale gelmiştir. Böylece yüksek işsizlik ve yoksulluk, siyasi ve ekonomik dışlanma ve çeşitli eşitsizliklerle karşı karşıya kalan Doğu eyaletlerinde radikal sağ ciddi bir taban bulmuştur.

Diğer taraftan solun Doğu eyaletlerindeki spesifik konumu da AfD olgusunu beslemiştir. Belirgin biçimde Almanya'da özellikle SPD'nin uzlaşmaz tavrı nedeniyle federal hükümetlerde yer alamayan Die Linke, yeniden birleşmenin ardından sola yönelik önyargıların kırılabilmesi için eyalet yönetimlerine katılmaya büyük önem göstermiş̧tir. Bunun yanında, 1990 sonrası dönemde yerel yönetim yasaları ve modellerinde önemli değişikliklerin yaşandığı ve eyaletlere göre yerel yönetim yapılanmalarının değiştiği ülkede, eyalet yönetimlerinin ve yerel yönetimlerin sundukları kamu hizmetleri ve yerel hizmetler -örneğin kültür, eğitim ve kamu güvenliği gibi alanlarda- ağırlı̆̆ını korumuştur (Sadioğlu, 2018: 31). Bu nedenle sol açısından eyalet deneyimlerinde başarılı olmak, aynı zamanda federal siyasette yükselmenin bir ön koşulu olarak düşünülmüştür.

Kamu politikası ve makro politikalar açısından hükümetlere katılarak daha demokratik, katılımcı, şeffaf, sosyal ve yeniden dağıtımcı bir düzenin inşa edilmesine yoğunlaşan sol aktör, özellikle "düşük gelirlileri, Hartz reformlarından etkilenenleri, işsizleri, gençleri ve devlet müdahalesi destekçilerini" önceleyen bir programla seçmenlerin karşısına çıkmış ve başarılı seçim sonuçları elde ettiği Doğu eyaletleri arasında yer alan Berlin, Mecklenburg-Vorpommern ve Türingiya'da çeşitli dönemlerde eyalet hükümetlerinde yer almıştır (McKay, 2012).

Hükümet deneyimleri sırasında partinin politika uygulamaları açısından ise farklı stratejiler izlediği görülmüsşür. Bu minvalde, örneğin Berlin'de, oy artışının sağlanması gibi tamamen pragmatik bir stratejinin etkisi altında kalarak güven sağlamaya yönelen parti, federal hükümetin neoliberal reformlarının bölgesel uzantılarına karşı sessiz kalırken; Türingiya'da ise işsizlik ve yoksulluk gibi sosyo-ekonomik problemleri çözmeye yönelerek federal uygulamalara karşı direnç göstermiştir (Hough $v d$., 2007; Olsen, Hough, 2007).

Söz konusu tutarsızlığın temel nedeni, federal cumhuriyetin başkentinde uygulanacak bir radikal programın partiye yönelik önyargıları derinleştirerek alternatif solun federal hükümette yer alma planlarını suya düşürme ihtimali olmuştur. Bununla birlikte federal hükümetle uyumlu görüntünün sağlanması için Berlin'de verilen tavizler, özellikle gençlerin partiyi terk etmesi sonucunu doğurmuştur (McKay, 2012: 231). Diğer yandan kemer sıkma çağında federal Alman hükümetlerinin eyalet ve yerel düzeylerde yapılan harcamalarda izledikleri kemer sıkma politikaları-örneğin 2009'da yasalaşan bir kanunla Almanya'da borçların frenlenmesi için eyalet hükümetlerinin 
harcamalarının sınırlandırılması gibi yasal düzenlemeler yoluyla (Potrafke $v d$., 2016)ve özellikle SPD'nin sert muhalefeti nedeniyle seçimlerde söz verilen sol politikaların uygulamaya sokulamaması gibi nedenler, sol programın uygulanmasını yapısal olarak imkânsız hale getirmiştir. Tüm bu nedenlerle Die Linke'nin Doğu'daki hükümet deneyimleri, vatandaşların beklentilerini karşılayamamıştır.

Öte yandan AfD'nin 'Doğu sorununu' politize ederek atılım dönemine girmesinde yabancı düşmanı ve İslam karşıı 'Batı'nın İslamlaşmasına Karşı Vatansever Avrupalılar' (PEGIDA) örgütünün faaliyetleri de etkili olmuştur. Ekim 2014'te Naziler dönemine açı biçimde sempati duyan dazlakların güçlü olduğu Doğu Almanya'nın önemli merkezlerinden Dresden'de kurulan PEGIDA'nın öncülük ettiği toplumsal protestolar, bölgedeki genel memnuniyetsizliğin bir dışavurumudur (Dostal, 2015). Ülkedeki azımsanamayacak sayıdaki Türkiye göçmeni nüfusu da hesaba katarak Almanya'nın hızla Müslümanlaştırıldığını savunan örgüt, İslam karşıtllğıını benimsemiştir.

Söz konusu yapının kurulmasına paralel olarak ülkede göçmenlere yönelik şiddet olayları hız kazanmıştır. Ne var ki siyasi kaygıların ön plana çıktığı iktidar kanadı, aşırı sağla mücadelede pasif kalmıştır (Wolf, 2015: 87). Büyüyen sosyal sorunlara düşük asgari ücretin yasalaştırılması gibi palyatif önlemlerle yanıt veren federal hükümet, kamusal söylemi belirleme noktasında da vasat bir performans sergilemiştir. Merkez partilerinin sessiz onayıyla siyasi rekabetin temel dinamiklerini belirleyen aktör konumuna yükselen AfD, son tahlilde toplumsal tabanını genişleterek ülkede savaş sonrası dönemde ilk kez CDU/CSU'nun sağında istikrarlı ve güçlü bir partinin ortaya çıkmasına zemin hazırlamışırı.

Siyasi açıdan değerlendirildiğinde, yeni politika alanlarına açılarak Alman parti sisteminin geleneksel ayarlarını kökünden sarsan AfD'yle mücadelede ön plana çıkan temel aktör Die Linke olmuştur. Göçmenlere yönelik öfkeli açıklamalar yerine dayanışmaya ve savaş karşıtlığına vurgu yapan parti, alternatif göçmen söylemini benimsemiştir. Örneğin, bu itibarla, "göçmen krizinin doğal kaynakların ve insan emeğinin sömürülmesine dayanan ekonomik sistemdeki eşitsizliklerin doğal bir ürünü olduğu, orta sınıfların sosyal istikrarsızlıkla tehdit edilerek korku toplumu yaratıldığı ve zenginler ve yoksullar arasındaki uçurumun düzenli biçimde artmasının göçmen karşıtı duyguları güçlendirdiğì” iddia edilmiştir (Bouma, 2016).

Ne var ki göçmen meselesinde toplumsal algıyı ters yüz etmeyi amaçlayan radikal solun dayanışmacı söylemi, 2016'da Köln'deki yılbaşı kutlamaları sırasında meydana gelen taciz skandalları ve sığınmacı sayısının düzenli biçimde artmasını başarılı biçimde politize eden radikal sağ nedeniyle gözden düşmüştür. Bu nedenle 
sosyal adalet, adil vergilendirme ve güçlü refah devleti gibi taleplere yönelik toplumsal ilgi, 2017 seçimleri öncesinde zayıflamıştır.

\subsection{Alman Siyasetinde Yeniden Gruplaşma Eğilimi ve 2017 Seçimleri}

Bu koşullar altında 24 Eylül 2017 tarihinde gerçekleştirilen federal seçimleri yüzde 26.8 oyla 200 vekil elde eden CDU ilk sırada tamamlarken, SPD yüzde 20.5 oyla 153 vekilde kalmıştır. Bu partileri yüzde 12.6 oy ve 94 vekille AfD, yüzde 10.7 oy ve 80 vekille FDP, yüzde 9.2 oy ve 69 vekille Die Linke, yüzde 8.9 oy ve 67 vekille Yeşiller ve yüzde 6.2 oy ve 46 vekille CSU izlemiştir.

Federal seçimlerin en ilgi çekici sonucu, AfD'nin büyük bir siçrayış gerçekleştirerek parlamentonun en büyük üçüncü partisi olmasıdır. Aynı zamanda bu sonuç, Almanya'da savaş sonrası dönemde CDU/CSU'nun sağında yer alan bir partinin elde ettiği en büyük başarı olarak kayıtlara geçmiştir. AfD'nin elde ettiği başarıya benzer biçimde son y1llarda gözden düşen FDP de yeniden ivme kazanarak Hristiyan demokratlara yönelik siyasi memnuniyetsizliğin kazananları arasında yer almıştır.

Solda ise seçimlerin kaybedeni, bir önceki seçime kıyasla yüzde 5'in üzerinde oy kaybeden SPD olmuştur. Kızıl - yeşil hükümet deneyiminin ardından ideolojik, programatik ve stratejik önceliklerini belirleme noktasında ciddi kafa karışıklıkları yaşayan sosyal demokratlar, seçmenlerin oy verme davranışının değişmesinde belirleyici olmuştur. Doğu'da AfD'nin meydan okumasına rağmen istikrarlı bir sonuç elde eden Die Linke ise her ne kadar sosyal demokratların düşüşünden yararlanan temel aktör olmayı başaramasa da, parti sistemindeki pozisyonunu sağlamlaştırmıştır.

AfD'nin varlığına rağmen ve 2019 Berlin eyalet seçimlerini Die Linke'nin kazanması örneğinde açık biçimde görüldüğü üzere, günümüzde radikal sola oy veren seçmenler, ağırlıklı olarak eski Doğu Alman eyaletlerinde yaşamayı sürdürmektedir. Bu durumun başlıca nedeni, yeniden birleşme öncesinde verilen sözlerin aksine, bölgenin günümüzde dahi Batı Alman ekonomisine ve sosyal yapısına tam olarak entegrasyonunun sağlanamamasıdır.

Çok erken ve çok hızlı biçimde gerçekleşen birleşme süreci nedeniyle Doğu'da beliren sorunlar, hala çözüm beklemektedir. Almanya'da uzun yıllara yayılan güçlü büyüme eğilimine karşılık, ortaya çıkan refahtan yeterince pay alamayan bölge vatandaşları, Batı Alman kurumlarına ve ordoliberal ekonomik düzene tepkiyle yaklaşarak solun sosyal adalet talebini desteklemeyi sürdürmektedir. Birleşmenin ardından ikinci sınıf vatandaş statüsüne düşen Doğu halkı, günümüzde bölgedeki güçlü sosyalist kültürden ve geçmişin dayanışma kültürüne, toplumsal yapısına ve cömert 
refah devletine duyulan 'Ostalgie'den (nostalji) yararlanmaya devam etmektedir (Sierp, 2009).

Doğu'daki yadsınamaz etkisine rağmen radikal solun bölgedeki başarılarının geri döndürülemez olduğunu savunmak ise güçtür. Literatürde partinin bölgedeki geleceğine ilişkin olarak geliştirilen 2 hipotez mevcuttur. Bunlardan ilki olan yakınsama hipotezinde (convergence hypothesis), Doğu ve Batı Alman eyaletlerinin zamanla sosyo-yapısal açıdan birbirlerine benzeyeceği ve böylece iki bölge arasında eşitsizlik yaratan ekonomik, sosyal ve politik koşulların zamanla ortadan kalkacağ savunulmaktadır (Doerschler, 2015: 380). Bu durumun radikal solun oylarını gerileteceği iddia edilmektedir.

Buna karşl1ık rraksama hipotezinde (divergence hypothesis) ise, Alman vatandaşlarının esas olarak iki farklı siyasal kültür altında sosyalleşmeleri ve süregiden bölgesel eşitsizlikler nedeniyle bölgeler arasındaki farklı siyasal davranışların süreceği öngörülmektedir (Doerschler, 2015: 380). Her ne kadar farklı sorunlar ve talepler üzerinden yeni aktörlerin parti sistemine eklemlenmesi mümkünse de, mevcut koşullar altında Doğu eyaletlerinin ekonomik gelişmişlik ve refah düzeyi açısından Batı'dakilerin oldukça gerisinde kalması ile ana akım siyasi aktörler marifetiyle Doğu sorununun çözümsüzlüğe terk edilmesi gibi nedenlerle Die Linke'nin bölgedeki 'Volkspartei' (halk partisi) konumunun sürmesi daha olası görünmektedir. Bununla birlikte son yıllarda AfD'nin bölgede güç kazanması ise radikal solun işinin eskisi kadar kolay olmadığını kanıtlamaktadır.

\section{SONUÇ}

SPD'nin Alman toplumunda büyük kabul görmüş taleplerine (sosyal adalet, yeniden dağıtım, aktif sendikalar ve güçlü sosyal koruma gibi) yabancılaşarak neoliberal uzlaşıya eklemlenmesine karşllı Die Linke, ulusal parti sisteminde sosyal demokratların terk ettiği alana kaymıştır. Kemer sıkma mantığına yapısal olarak karşı çıkan radikal sol, ana akım aktörlerden ayrışarak Alman hükümetlerinin izlediği politikalara karşı oluşan öfkeden siyasi olarak yararlanmayı başarmıştır. Böylece daha çok eski sosyal demokrat seçmenlerin desteğini alan parti, toplumsal tabanını genişletmiştir. Bu durum, Alman solunda yeniden gruplaşma eğiliminin sınırlı da olsa söz konusu olduğunu ortaya koymaktadır.

Buna karşılık, Alman sağında ise h AfD, toplumsal öfkenin ülkede sayıları hızla artan göçmenler ile beceriksiz yönetimlere ve tembel halklara ev sahipliği yaptığını iddia ettiği çevre ülkelere çevrilmesi sonucunu doğurmuştur. Siyasi kaygıları ön plana çıkan ana akım aktörlerin de benzer bir yaklaşımı benimsemesiyle AfD, gerek kamusal söylem gerekse de parti rekabetini belirleyen meseleler üzerinde etkili olmuştur. 
Sonuç olarak, ulusal parti sisteminin hâkim aktörleri, kemer sıkma çağında (popülist) radikal solun ve sağın tazyiki altında kalarak gerileme dönemine girmiştir. Böylece Alman parti sistemi yeniden yapılandırılmış ve Güney Avrupa parti sistemlerinde gözlemlendiği kadar yıkıcı olmasa da, merkez ülkelerde de siyasi ayarların köklü değişimlere açık olduğu kanıtlanmıştır.

Günümüzde Doğu eyaletlerinde sağ popülizmin güçlü meydan okumasıyla karşı karşıya kalan radikal solun içerisinde bulunduğu siyasi tıkanıklığı aşmak için geliştirebileceği yöntemlerin başında, Batı eyaletlerine açılma stratejisi yer almaktadır. PDS - WASG birleşmesine rağmen günümüzde hala Batı eyaletlerindeki iş̧i sınıfi üzerinde ciddi bir etkiye sahip olmayan ve dolayısıyla bölgede yalnızca marjinal bir aktör konumunda bulunan Die Linke, her ne kadar son yıllarda Bremen (2019) ve Hamburg (2015) gibi eyaletlerde yapılan seçimlerde kısmi oy artışları sağlasa da, bölgedeki emekleme döneminin daha uzun yıllar süreceği ortadadır. Bu durumda Die Linke'nin parti sisteminde istikrarlı bir aktör olarak ön plana çıkmasının yanında, yeni bir atılım dönemine girmesi, kısa vadede pek de mümkün görünmemektedir.

Diğer yandan SPD'nin dümeni yeniden sola kırması halinde radikal solun memnuniyetsiz sosyal demokrat seçmenleri kaybetme riski bulunmaktadır. Ne var ki 2017 yılında SPD’nin liderliğine seçilen Martin Schulz'un birkaç gönülsüz girişiminin ardından parti ideolojisinin ve programının yeniden belirlenme çabasının başarısızlığa uğraması, sosyal demokratlarda belirsizlik ikliminin alternatif solu güçlendirecek biçimde sürmesinin daha olası olduğunu düşündürmektedir.

\section{KAYNAKÇA}

Akçay, Ü., A.R. Güngen (2016), Finansallaşma, Borç Krizi ve Çöküss: Küresel Kapitalizmin Geleceği, Ankara: NotaBene Yayınları.

Arzheimer, K. (2006), “'Dead Men Walking?' Party Identification in Germany, 1977-2002", Electoral Studies, 25, 791-807.

Arzheimer, K. (2015), "The AfD: Finally a Successful Right-Wing Populist Eurosceptic Party for Germany?", German Politics, 38(3), 535-556.

Bailey, D.J. (2016), "Capitalist Crisis or Crisis of Capitalism? How the Radical Left Conceptualises the Crisis", in L. March, D. Keith (eds.), Europe's Radical Left: From Marginality to the Mainstream?, London and New York: Rowman \& Littlefield, 51-70.

Berbuir, N., M. Lewandowsky, J. Siri (2015), "The AfD and its Sympathisers: Finally a RightWing Populist Movement in Germany?", German Politics, 24(2), 154-178.

Bieling, H.J. (2012), "European Governance: On the Relationship Between Democratic and Nondemocratic Deliberation Within the European Multi-level System", World Political Science Review, 8(1) 201-216. 
Bieling, H.J. (2014), "Shattered Expectations: The Defeat of European Ambitions of Global Financial Reform", Journal of European Public Policy, 21(3), 346-366.

Bouma, A. (2016), "Ideological Confirmation and Party Consolidation: Germany's Die Linke and the Financial and Refugee Crises,", in L. March, D. Keith (eds.), Europe's Radical Left: From Marginality to the Mainstream?, London and New York: Rowman \& Littlefield, 133-154.

Bowyer, B.T., M.I. Vail (2011), "Economic Insecurity, the Social Market Economy, and Support for the German Left", West European Politics, 34(4), 683-705.

Cahuc, P., S. Carcillo, U. Rinne, K. F. Zimmermann (2013), "Youth Unemployment in Old Europe: The Polar Cases of France and Germany", Journal of European Labor Studies, 2(18), 1-23.

Charalambous, G. (2011), “All the Shades of Red: Examining the Radical Left's Euroscepticism”, Contemporary Politics, 17(3), 299-320.

Çubukçu, S.U. (2013), “Sosyal Demokrasi: Melez Bir Politik Gelenek”, in H. B.Örs (ed.), 19. Yüzyıldan 20. Yüzyıla Modern Siyasal İdeolojiler, İstanbul: İstanbul Bilgi Üniversitesi Yayınları, 253-306.

Die Linke Parti Programı (2011), https://en.diel inke.de/fileadmin/download/english_pages/progra mme_of_the_die_linke_party_erfurt_2011.pdf, E.T.: 05.07.2019.

Dingelday, I. (2007), "Between Workfare and Enablement - The Different Paths to Transformation of the Welfare State: A Comparative Analysis of Activating Labour Market Policies", European Journal of Political Research, 46, 823-851.

Doerschler, P. (2015), “Die Linke: Still an Eastern Cultural Icon?”, German Politics, 24(3), 377 401.

Dostal, J.D. (2015), "The Pegida Movement and German Political Culture: Is Right-Wing Populism Here to Stay?”, The Political Quarterly, 86(4), 523-531.

Dyson, K. (2008), "A Crisis of Leadership in the Euro Area," The Euro at 10: Europeanization, Power, and Convergence, Ed. by. Kenneth Dyson, Oxford-New York, Oxford University Press, 2008, 132-164.

Eisenberg, C.W. (1996), Drawing the Line: The American Decision to Divide Germany, 19441949, Cambridge: Cambridge University Press.

Faas, T. (2015), “The German Federal Election of 2013: Merkel's Triumph, the Disappearance of the Liberal Party, and Yet Another Grand Coalition", West European Politics, 38(1), 238-247.

Hildebrandt, C. (2011), "The Left Party in Germany", in B. Daiber, C. Hildebrandt, A. Striethorst (eds.), From Revolution to Coalition - Radical Left Parties in Europe, Berlin: RosaLuxemburg Foundation, 93-113.

Hildebrandt, C. (2013), “A Political Earthquake in Germany”, Transform, 13, 149-154.

Hough, D. (2010), "From Pariah to Prospective Partner? The German Left Party's Winding Path towards Government", in (J. Olsen, M. Kob, D. Hough (eds.), Left Parties in National Governments, London: Palgrave Macmillan, 138-154. 
Hough, D., M. Koß (2009), "Populism Personified or Reinvigorated Reformers? The German Left Party in 2009 and Beyond", German Politics and Society, 27(2), 76-91.

Hough, D., M. Koß, J. Olsen (2007), The Left Party in Contemporary German Politics, New York: Palgrave Macmillan.

Hudson, K. (2000), European Communism since 1989: Towards a New European Left?, Basingstoke: Macmillan.

Jackle, S., P.D. König (2017), “The Dark Side of the German 'Welcome Culture': Investigating the Causes behind Attacks on Refugees in 2015”, West European Politics, 40(2), 223 251.

Kitschelt, H., W. Streeck (2003), "From Stability to Stagnation: Germany at the Beginning of the Twenty-first Century”, West European Politics, 26(4), 1-34.

Küçükali, C. (2014), “The Perceptions, Attitudes and Political Strategies of 'Die Linke': A Political Discourse Analysis”, GeTMA Working Paper Series, 2, 1-72.

Major, P. (1997), The Death of the KPD: Communism and Anti-Communism in West Germany, 1945-1956, New York: Oxford University Press.

March, L., C. Mudde (2005), "What's Left of the Radical Left? The European Radical Left After 1989: Decline and Mutation", Comparative European Politics, 3, 23-49.

McGiffen, S. (2011), "Bloodless Coup d'Etat: The European Union's Response to the Eurozone Crisis", Socialism and Democracy, 25(2), 25-43.

McKay, J. (2017), “The Berlin Land Election 2011”, German Politics, 21(2), 228-238.

Mewes, H. (1983), "The West German Green Party”, New German Critique, 28, 51-85.

Nachtwey, O., T. Spier (2007), "Political Opportunity Structures and the Success of the German Left Party in 2005”, Journal of Contemporary Central and Eastern Europe, 15(2), 123 154.

Neumayer, C. (2016), “Contested Hashtags: Blockupy Frankfurt in Social Media”, International Journal of Communication, 10, 5558-5579.

Olsen, J. (2007), "The Merger of the PDS and WASG: From Eastern German Regional Party to National Radical Left Party?", German Politics, 16(2), 205-221.

Olsen, J. (2018), "The Left Party and the AfD: Populist Competitors in Eastern Germany?", German Politics and Society, 36(1), 70-83.

Olsen, J. (2007), “Don't Think Twice, It's Alright: SPD - Left Party / PDS Coalitions in the Eastern German Länder", German Politics and Society, 25(3), 1-24.

Oppelland, T. (2012), "Rituals of Commemoration - Identity and Conflict: The Case of Die Linke in Germany", German Politics, 21(4), 429-443.

Patton, D.F. (2013), "The Left Party at Six: The PDS - WASG Merger in Comparative Perspective", German Politics, 22(3), 219-234.

Potrafke, N., M. Riem, C. Schinke (2016), "Debt Brakes in the German States: Governments' Rhetoric and Actions", German Economic Review, 17(2), 253-275.

Proksch, S - O., J.B. Slapin (2006), "Institutions and Coalition Formation: The German Election of 2005”, German Politics, 21(2), 540-559. 
Saalfed, T. (1990), “The West German Bundestag After 40 Years: The Role of Parliament in a 'Party Democracy", West European Politics, 13(3), 68-89.

Sadioğlu, U. (2018), Türkiye ve Almanya'da Yaşanan Yerel Yönetimler Reformunun Karşılaştırılması: Yeni Bir Model Önerisi, Ankara: Seçkin Yayıncılık.

Sierp, A. (2009), "Nostalgia for Times Past. On the Uses and Abuses of the Ostalgie Phenomenon in Eastern Germany", Contemporary European Studies, 4(2), 47-60.

Solty, I. (2008), "The Historic Significance of the New German Left Party", Socialism and Democracy, 22(1), 1-34.

Storm, S., C.W.M. Naastepad (2015), "Crisis and Recovery in the German Economy: The Real Lessons", Structural Change and Economic Dynamics, 32, 11-24.

Taylor, R. (2009), "Europe's Divided Left”, Dissent, 56(2), 5-9.

Wolf, F.O. (2015), “The Radical Left in Germany”, Socialism and Democracy, 29(3), 81-92.

Zur, Roi. (2017), "When Valence Crushes: Explaining the Electoral Failure of the German FDP in the 2013 Election", German Politics, 26(3), 380-397. 